\title{
Circles around the farm animal embryo - a Danish perspective
}

\author{
H. Callesen ${ }^{1}$ \\ Department of Animal Science, Aarhus University, Tjele, Denmark.
}

\begin{abstract}
With focus on the farm animal embryo, a short overview is given about my research activities over the last 35 years. These activities have been described in five circles, covering different key aspects of my work. The first circle included studies on the basic biology related to oocyte maturation and follicular endocrinology in superovulated dairy cows. Methods were developed to characterize the donor cows with respect to their production of transferable embryos, and some were implemented into a Danish MOET breeding plan. The second circle dealt with in-vitro embryo production in cattle with development of a protocol to produce such embryos at high and consistent levels. Several comparisons were made to reveal consequences of the artificial in-vitro methods on oocytes and embryos, but also through studies of the newborn calves. The third circle was related to development and implementation of a number of technologies within this broad field; examples are mentioned for both oocyte recovery from donor cows, different steps in the in-vitro embryo production system, new ways to perform vitrification and nuclear transfer, and finally a new system to determine oxygen consumption in single embryos. In the fourth circle is described activities from the last years, where work was done with focus on the pregnancy rates after insemination of the dairy cow in their post-partum period, and where somatic cell nuclear transfer was developed both as a technology in itself as well as a helping technique to produce transgenic pigs as models for important human diseases. The fifth and final circle is addressing and thanking the many colleagues and collaboration partners that I have been involved with during all the years to do this work. Nothing could or would have been the same without them and their participation.
\end{abstract}

keywords: cattle, embryo technology, pig, reproductive biology, overview.

\section{Introduction}

My first AETE meeting was in 1987 in Lyon where the 3rd meeting was held. Since I have been at all but three of these annual highlights, and at every meeting I have been listening with interest to the distinguished scientists receiving the AETE award. Today, it is my privilege and honor to be that person, and since I was told this great news a year ago, I have gradually learned to use this opportunity and reflect over my scientific career in ways that I usually do not.

Having worked with farm animal embryos for more than 30 years gives many possibilities to do different things. My choice - to some extent also influenced by coincidences - has been to focus on the farm animal embryo in kind of circles around the days before, during and after fertilization, and I have always had Denmark as the center for my activities. Within those frames, most of my research interests have been divided between biology and technologies, from a basic to an applied aspect, and then using collaborations very much.

So, it has been fairly limited circles, made in a rather small country, and always with the embryo in focus. In the following, I will give a short overview of my scientific activities using some kind of a chronological approach. It will not be a real literature review, but a selfcentered presentation. This is not often allowed, but on this special occasion I think it is. To prepare this has been interesting for me, but of course I hope that it will also be that for at least some of you.

\section{The superovulated donor cow}

From the beginning of the 1980ies, I started as Torben Greve's first PhD-student at the Royal Veterinary and Agricultural University in Copenhagen. He had been very much involved in establishing the basics on superovulation and embryo transfer in cattle, also in practice, but time had come to search for a better understanding of some of the reasons for the often varying and rather unpredictable results. Together with another PhD-student, Poul Hyttel, my first years in research were therefore focused on morphological and endocrine aspects of the preovulatory period in superovulated dairy cattle. What were the actions and consequences of the exogenous FSH treatment on the developing follicles and oocytes? Poul's focus was ultrastructure, while mine was the hormones and the more clinical and applied aspects.

Over several years we used more than 130 cows and heifers to study preovulatory oocyte morphology and follicular endocrinology and to describe their overall reaction patterns, and to relate these to the resulting oocyte and later embryo quality. Some of the main results were presented at my first IETS conference held in Colorado Springs in 1986 (Callesen et al., 1986), where characteristics of donors with good versus bad oocytes were presented. This was followed by several also more practice-related studies (e.g. Callesen et al., 1995) also to identify the good or bad donors. For this, donors were characterized through their patterns of progesterone or estradiol concentrations in plasma and milk (Callesen et al., 1988, 1990) together with detailed estrus observations (Callesen et al., 1993c), or by use of ultrasound examinations of follicular

${ }^{1}$ Corresponding author: henrik.callesen@anis.au.dk 
development and ovulation (Purwantara et al., 1993, 1994). Also in these years, problems associated with the FSH preparations used for superovulation (e.g. causing premature ovulations, Callesen et al., 1987b) were addressed by attempts to control the superovulatory reaction by use of anti-PMSG (Callesen et al., 1992) or by controlling the LH-contents (Schmidt et al., 1988).

On the practical side, larger projects based on MOET breeding plans were started in Europe, also in Denmark, where I got involved in such a project after having left Copenhagen and moved to Foulum in the western part of Denmark. This resulted in work on e.g. donor selection (Greve and Callesen, 1989), but we also made several studies on the embryo recipients; some of this work was presented at several AETE-meetings (Callesen et al., 1993a, b; 1994a, b). The contact to practice also gave some challenges when the more theoretical and experimental work met the real practical world (Liboriussen et al., 1995; Callesen et al., 1996), for example with the breeding potentials following the realized outcome of superovulation (Callesen et al., 1994c).

\section{In vitro production of bovine embryos}

During the 1980ies, the procedure for in vitro production of bovine embryos was being established based on work around the world with the first IVF calf reported from USA in 1983. In Copenhagen, Kang Pu $\mathrm{Xu}$ - another of Torben Greve's PhD-students - worked hard on this technology (e.g. Xu et al., 1987), and a prominent result was achieved when the first IVP calf in Europe was born here in 1987 (Greve et al., 1989).

In my Foulum-group we worked several years to optimize the bovine IVP-procedure. Peter Holm went through the tedious work of testing close-to-everything in relation to media and conditions for in vitro production (e.g. Holm et al., 1994, 1995), before this resulted in a quite useful modified SOF medium (Holm et al., 1999). Parallel to this work, we were still interested in morphological differences between vivo versus vitro oocytes (e.g. Hyttel et al., 1989b), also illustrating some of the implications for vivo and vitro fertilization (e.g. Hyttel et al., 1989a, 1991). At the AETE meeting in Venice, some of this work was summarized (Holm and Callesen, 1998).

With the gradual improvement of the IVP systems, we got a stronger interest in some of the consequences of such artificial in vitro conditions, stimulated by the disturbing reports about the so-called Large or Abnormal Offspring Syndrome. Thus, we worked on differences between vivo versus vitro embryos, both in cattle and pig (e.g. Hyttel et al., 2000), on chromosomal problems after in vitro production (Viuff et al., 1999), and finally also on the resulting calves (Jacobsen et al., 2000). As part of these studies, I spent some months in New Zealand and Australia in 2001 to study pregnancies and calves after both IVP and cloning. In Europe, these concerns were also subject for many discussions in the public with focus on animal ethics (e.g. Callesen et al., 1999), and also at the AETE meetings, where questionnaires were the basis for workshop discussions in e.g. Santander (den Daas and Callesen, 2000).

\section{The tools for working with reproductive technologies}

To work in such a biological area, technologies are required, and over the years I have been involved in several such technical developments in quite different fields.

\section{Ovum pick-up}

Oocyte collection through the abdominal wall was developed in the human field in the first part of the 1980ies, and together with a medical doctor we made some of the first attempts in cattle. It was a para-lumbar approach (presented at the 1987 IETS meeting; Callesen et al., 1987a), and several lessons were made - one was that it can result in recovery of oocytes, but also that a cow patient will kick you when you prick her with a needle; a big surprise for the medical doctor! Soon after, especially the group from Utrecht led the way into the much more convenient vaginal approach that also became routinely used in human.

\section{In vitro embryo culture}

We continued to work on in vitro culture, driven by Gabor Vajta's urge for simplicity and reliability. One area was an incubator system based on having the culture dish in a foil bag that was submerged into a water bath (Vajta et al., 1997b). This provided very stable temperature conditions, required minimal use of gases, and each culture dish had its own chamber. However, only few would - and will - accept a water bath in their culture lab. Another area was related to the anticipated need for an embryo to establish a local in vitro environment during its development. This was obtained by hand-making small holes or impressions in the bottom of standard plastic dishes (Vajta et al., 2000). The method was subject for a course also given at the AETE meeting in Lyon in 2004. A third interest was to see how far the embryo actually could be cultured in vitro (Brandão et al., 2004; Vajta et al., 2004). We learned that the trophoblastic cells grew quite well to form up to an almost $2 \mathrm{~cm}$ long structure ... but the very early embryo proper did not.

\section{Time-lapse systems}

To study embryo morphology frequently during in vitro culture, Peter Holm built his own timelapse system in the mid-1990ies (Holm et al., 1998). This was a fairly simple and cheap system, but it provided what was needed from the oocyte's and embryo's point of view, allowing complete, high and stable in vitro development for up to 9 days together with taking pictures every 20-30 $\mathrm{min}$. The resulting films were rather boring during IVM, but there was much more to see when monitoring the pre-implantation period in both cattle (e.g. Holm et al., 2002) and pig (e.g. Callesen and Holm 2016), also with cloned and parthenogenetic embryos (Holm et al., 2003). Through 
this work I established an interesting collaboration with the Danish company Unisense A/S that later developed the EmbryoScope $\AA$, an instrument that today is used in several human fertility clinics around the world.

\section{Vitrification}

A challenge in cryopreservation was the more fragile types of eggs, such as oocytes in general and embryos from certain species such as the pig; none of these structures really tolerated traditional slow freezing. Parallel to a visit from Masashige Kuwayama (Kuwayama et al., 1997), the vitrification technology was taken further by Gabor Vajta, resulting in a thinstraw system (Vajta et al., 1998). Now also early-stage embryos from both cattle and pig became possible to cryopreserve (Vajta et al., 1997a, c). An impressing illustration of the potentials of this technology was three calves born after having been vitrified/warmed two times before transfer: first as in vitro matured oocytes, second as blastocysts after in vitro fertilization and in vitro culture (Vajta et al., 1998).

\section{Oxygen consumption}

Working with embryos, it has for a long time been a wish to complement the morphological evaluations of embryo development with functional measures. Together with the company Unisense A/S, experts in microsensor technology, we established a system for measuring oxygen consumption from single embryos, using the bovine as a model. Together with a Portugese PhD-student, Ana Lopes, we used it for single-day measurements first on in vitro produced embryos (Lopes et al., 2005), but later also on flushed vivo embryos, that were afterwards transferred, illustrating the relation between embryo "respiration" and viability (Lopes et al., 2007b). In another approach, we installed the oxygen consumption system inside the previously mentioned time-lapse system, so repeated oxygen measurements could be made on the same embryos during seven days of in vitro culture, resulting in very detailed oxygen consumption curves (Gundersen et al., 2006, reviewed by Lopes et al., 2007a). The technology thus works, but its technical complexity has so far not made it useful for other than special research purposes.

\section{Using the basic circles in a wider context}

My focus on the embryo for several years, having interest in both biological and technological issues, has taken me into a number of broader applications.

One was to question our traditional approach where we attempt to make the conditions for the embryos as pleasant as possible during their stressful in vitro period (Callesen et al., 2012) and instead combine the various methods into a pro-active and challenging testing system to select the most robust embryos. This so far theoretical idea was subject for an IETS presentation in Argentina (Callesen et al., 2010), but it still remains theoretical.

A second area was in the post-partum cow, in which period oocyte and embryo qualities are key issues when it comes to establishment of a new pregnancy. The start of estrus cyclicity requires the endocrine systems to be in positive balance with the follicular development in the ovaries, and a successful outcome after insemination requires the whole reproductive system to be ready-for-use. In three different studies, indirect measures for these internal events were studied with particular reference to use in practice. In one, the vaginal discharge was characterized during the first period after calving and related to the cow's progesterone profiles (Gorzecka et al., 2011a, b, c). In another, focus was on metritis in the same period, working on the bacterial population and its effect on reproduction, as well as establishing a uterine scoring system (Elkjær et al., 2013a, b) as basis for deciding when to perform the first insemination (Elkjær et al., 2013c). In the third study, estrus cyclicity and reproductive performances were followed for a longer period after calving, namely in a system with extended lactation (Gaillard et al., 2016).

The third area was somatic cell nuclear transfer of pigs ("cloning"). We have been working on this complex technology over more than 20 years, first in cattle with birth of calves as a result (Smith et al., 1994), since in cattle and pigs with a zona-free approach (Booth et al., 2001a, b), and then with Gabor Vajta's handmade-cloning system (HMC; Vajta et al., 2003; Kragh et al., 2004) that resulted in the first piglets born in 2006 (review by Vajta and Callesen, 2012). The HMC system was going through a number of optimizations for example with different cytoplasmic volumes (Li et al., 2015) and with gilt versus sow oocytes (Li et al., 2014; Pedersen et al., 2015). Further, different pre-treatments were tested with cells and oocytes being exposed to a frog extract (Liu et al., 2014) or embryos to a high pressure treatment (Lin et al., 2014). Another very important side of our cloning work was related to the recipient animal, both in their selection and pre-treatment, but also with the transfer method used (Schmidt et al., 2010). Finally, the outcome was also being analyzed thoroughly (Liu et al., 2015), both related to the period around birth and to the piglets born with their reasons for not surviving this challenging procedure (Schmidt et al., 2011, 2015). Combining all these aspects, we built up a system that over four years produced very satisfying results (Callesen et al., 2014), and today we have a number of cloned piglets that are transgenic for different serious human diseases (e.g. Luo et al., 2011; Staunstrup et al., 2012; Al-Mashhadi et al., 2013; Jakobsen et al., 2014 and more are coming). Over the next years, the medical doctors will reveal if these transgenic piglets can serve as useful animal models for the different diseases.

\section{To all my collaborators}

The type of research that I have described does not work well if you are sitting alone on a desert island with some paper and a pencil ... no, we need each other. 
In the different activities, we can have different roles, influenced by background education, experience, time etc. For all of these activities described above, I believe to have had a significant role in making them happen, but all have only been possible because we have been working as a group. We have never been a large group and Denmark is not a large country. However, Torben Greve learned me the importance of travelling around, meeting colleagues, presenting at scientific meetings. It may mean some fairly big travel expenses, but it is worth it. I first saw that as a young PhD-student at my first international meeting in 1983 in Helsinki, and since I have been at many such meetings at IETS, AETE, SBTE, ICAR and several others to meet you, discuss with you and visit you. From such an approach, even the small Danish groups have been around for some years now, and surprisingly, one of the Danes now stands here on this occasion. So, size does not always matter, if I may say so.

\section{Final remarks}

Through the years I have been working around the farm animal embryo in the days before, during and after fertilization, and this has been done in different species, in different contexts, with different technologies, in different collaborations. From such a view, I may have become a generalist in this field, but I still do consider the superovulated cow to have a special place in my scientific heart.

Speaking about my heart: My almost 35 years in research - so far - have given me so many contacts to colleagues, and today I am lucky and proud to consider quite many of you to have become friends. Thanks to all I have met during this travel around the embryo, nothing like that could or would have been done without you.

\section{References}

\section{Selected and self-centered references for this overview}

Al-Mashhadi RH, Sørensen CB, Kragh PM, Christoffersen C, Mortensen MB, Tolbod LP, Thim T, Du Y, Li J, Liu Y, Moldt B, Schmidt M, Vajta G, Larsen T, Purup S, Bolund L, Nielsen LB, Callesen H, Falk E, Mikkelsen JG, Bentzon JF. 2013. Familial hypercholesterolemia and atherosclerosis in cloned minipigs created by DNA transposition of a human PCSK9 gain-of-function mutant. Sci Transl Med, 5:166ra1.

Booth PJ, Tan SJ, Holm P, Callesen H. 2001a. Application of the zona-free manipulation technique to porcine somatic nuclear transfer. Cloning Stem Cells, 3:191-197

Booth PJ, Tan SJ, Reipurth R, Holm P, Callesen H. 2001b. Simplification of bovine somatic cell nuclear transfer by application of a zona-free manipulation technique. Cloning Stem Cells, 3:139-150.

Brandão DO, Maddox-Hyttel P, Løvendahl P, Rumpf R, Stringfellow D, Callesen H. 2004. Post hatching development (PHD): a novel system for extended in vitro culture of bovine embryos. Biol Reprod, 71:2048-2055.
Callesen H, Greve T, Hyttel P. 1986. Preovulatory endocrinology and oocyte maturation in superovulated cattle. Theriogenology, 25:71-86.

Callesen H, Greve T, Christensen F. 1987a. Ultrasonically guided aspiration of bovine follicular oocytes. Theriogenology, 27:217. (abstract).

Callesen H, Greve T, Hyttel P. 1987b. Premature ovulations in superovulated cattle. Theriogenology, 28:155-166.

Callesen H, Greve T, Hyttel P. 1988. Preovulatory evaluation of the superovulatory response in donor cattle. Theriogenology, 30:477-488.

Callesen H, Greve T, Hyttel P, Bak A, Gotfredsen P, Holm P. 1990. Preovulatory plasma estradiol-17ß concentrations and ovulation rates in PMSG/anti-PMSG treated heifers. Theriogenology, 34:251-258.

Callesen H, Bak A, Greve T. 1992. Use of PMSG antiserum in superovulated cattle? Theriogenology, 38:959-968.

Callesen H, Bak A, Greve T. 1993a. Spontaneous vs induced estrus in recipient cattle prior to non-surgical transfer of fresh or frozen/thawed embryos. In: Proceedings. Association Européenne de Transfert Embryonnaire, 1993, Lyon France. Lyon: AETE. pp. 176. (abstract)

Callesen H, Bak A, Greve T. 1993b. Transfer of embryos to recipient cows: Influence of side of previous pregnancy? In: Proceedings Association Européenne de Transfert Embryonnaire, 1993, Lyon France. Lyon: AETE. pp. 178. (abstract).

Callesen H, Greve T, Hyttel P. 1993c. Estrus characterization in superovulated cattle. Theriogenology, 40:1243-1250.

Callesen H, Bak A, Greve T. 1994a. Embryo recipients: dairy cows or heifers? In: Proceedings. Association Européenne de Transfert Embryonnaire, 1994, Lyon France. Lyon: AETE. pp. 125-135.

Callesen H, Bak A, Greve T. 1994b. Pregnancy failure following transfer of bovine embryos: Inherent low fertility of recipients? Theriogenology, 41:172. (abstract). Callesen H, Liboriussen T, Bak A, Greve T. 1994c. Realized reproductive efficiency in MOET nucleus breeding cattle herds. In: Proceeedings. 1st Integrated European Conference on Progress in Emb Tech and Genetic Engineering in Cattle and Sheep Breeding, 1994, Krakow Poland.Krakow: The Conference. pp. 97-102.

Callesen H, Løvendahl P, Bak A, Greve T. 1995. Factors affecting the developmental stage of embryos recovered on day-7 from superovulated dairy cattle. $J$ Anim Sci, 73:1539-1543.

Callesen H, Liboriussen T, Greve T. 1996. Practical aspects of multiple ovulation-embryo transfer in cattle. Anim Reprod Sci, 42:215-226.

Callesen H, Holm P, Greve T, Sandøe P. 1999. The role of biotechnology in farm animal breeding. In: Jensen KK, Andersen S (Ed.). Use of biotechnology in animal husbandry. Antology about bioethics [in Danish] Copenhagen: Rosinante Publishing. pp. 180-187.

Callesen H. 2010. Challenge testing of gametes to enhance their fertility. Reprod Fertil Dev, 22:40-46.

Callesen H. 2012. Challenges in work with bovine gametes and embryos. Anim Reprod, 9:341-344. 
Callesen H, Liu Y, Pedersen HS, Li R, Schmidt M. 2014. Increasing efficiency in production of cloned piglets. Cell Reprogram, 16:407-410.

Callesen H, Holm P. 2016. Developmental characteristics of later-stage porcine embryos produced in vivo or in vitro. Reprod Fertil Dev, 28:158. (abstract).

den Daas N, Callesen H. 2000. Minutes of the workshop on 'Animal Health and Welfare'. AETE Newslett, 11:14-16.

Elkjær K, Ancker M-L, Gustafsson H, Friggens NC, Waldmann A, Mølbak L, Callesen H. 2013a. Uterine bacterial flora in postpartum Danish Holstein dairy cows determined using DNA-based fingerprinting: correlation to uterine condition and calving management. Anim Reprod Sci, 138:39-48.

Elkjær K, Labouriau R, Ancker M-L, Gustafsson H, Callesen H. 2013b. Large-scale study on effects of metritis on reproduction in Danish Holstein cows. $J$ Dairy Sci, 96:372-377.

Elkjær K, Labouriau R, Ancker M-L, Gustafsson H, Callesen H. 2013c. Practical use of a uterine score system for predicting effects on interval from calving to first insemination and non-return rate 56 in Danish dairy herds. Vet J, 198:644-648.

Gaillard C, Barbu H, Sørensen MT, Sehested J, Callesen H, Vestergaard M. 2016. Milk yield and estrus behavior during eight consecutive estruses in Holstein cows fed standardized or high energy diets and grouped according to live weight changes in early lactation. J Dairy Sci, 99:3134-3143.

Gorzecka J, Callesen H, Pedersen KM, Friggens NC. 2011a. The relationship between postpartum vaginal discharge symptoms and progesterone profile characteristics in lactating dairy cows in Denmark Theriogenology, 75:1016-1028.

Gorzecka J, Codrea MC, Friggens NC, Callesen H. 2011b. Progesterone profiles around the time of insemination do not show clear differences between of pregnant and not pregnant dairy cows. Anim Reprod Sci, 123:14-22

Gorzecka J, Friggens NC, Ridder C, Callesen $\mathbf{H}$. 2011c. A universal index of uterine discharge symptoms from calving to 6 weeks postpartum. Reprod Domest Anim, 46:100-107.

Greve T, Callesen H. 1989. Selection and management of donor cattle: Improvement of embryo yield. In: Proceedings. Association Européenne de Transfert Embryonnaire, 1989, Lyon, France. Lyon: AETE. pp. 85-103.

Greve T, Xu KP, Callesen H, Hyttel P. 1989. Calves resulting from in-vitro fertilization of oocytes. Zuchthygiene, 24:79-83.

Gundersen, JK, Ramsing NB, Callesen H. 2006 Embryo quality assessment by respiration rate measurements and image analysis of time-lapse images during embryo development. In: Proceedings 17th Nordic Fertility Society Conference, 2006, Espoo Finland. Acta Obstet Gynecol Scand, 86:119. (abstract).

Holm P, Smith S, Callesen H. 1994. Post-thaw in-vitro viability of bovine blastocysts produced in-vitro in different media and gas atmospheres. In: Proceedings. Association Européenne de Transfert Embryonnaire,
1994, Lyon France. Lyon: AETE. pp. 182. (abstract).

Holm P, Vajta G, Greve T, Callesen H. 1995. Effect of different protein sources on in vitro development of bovine in vitro zygotes. In: Proceedings Association Européenne de Transfert Embryonnaire, 1995, Hannover, Germany. Hannover: AETE. pp. 190. (abstract).

Holm P, Callesen H. 1998. In vivo versus in vitro produced bovine ova: Similarities and differences relevant for practical application. In: Proceedings. Association Européenne de Transfert Embryonnaire, 1998, Venice, Italy. Venice, Italy: AETE. pp. 65-79.

Holm P, Shukri NN, Vajta G, Booth P, Bendixen C, Callesen H. 1998. Developmental kinetics of the first cell cycles of bovine in vitro produced embryos in relation to their in vitro viability and sex. Theriogenology, 50:12851299.

Holm P, Booth PJ, Schmidt MH, Greve T, Callesen H. 1999. High bovine blastocyst development in a static in vitro production system using SOFaa medium supplemented with sodium citrate and myo-inositol with or without serum-proteins. Theriogenology, 52:683-700.

Holm P, Booth PJ, Callesen H. 2002. Kinetics of early in vitro development of bovine in vivo and in vitro zygotes produced and/or cultured in chemically defined or serum containing media. Reproduction, 123:553-565.

Holm P, Booth PJ, Callesen H. 2003. Developmental kinetics of bovine nuclear transfer and parthenogenetic embryos. Cloning and Stem Cells, 5:133-142.

Hyttel P, Callesen H, Greve T. 1989a. A comparative ultrastructural study of in-vivo versus in-vitro fertilization of bovine oocytes. Anat Embryol, 179:435-442.

Hyttel P, Greve T, Callesen H. 1989b. Ultrastructural aspects of oocyte maturation and fertilization in cattle. $J$ Reprod Fertil Suppl, 38:35-47.

Hyttel P, Callesen H, Greve T, Schmidt M. 1991. Oocyte maturation and sperm transport in superovulated cattle. Theriogenology, 35:91-108.

Hyttel P, Viuff D, Laurincik J, Schmidt M, Thomsen PD, Avery B, Callesen H, Rath D, Niemann H, Rosenkrantz C, Schellander K, Ochs RL, Greve T. 2000. Risks of in-vitro production of cattle and swine embryos: aberrations in chromosome numbers, ribosomal RNA gene activation and perinatal physiology. Hum Reprod, 15(suppl. 1):87-97.

Jacobsen H, Schmidt M, Holm P, Sangild PT, Vajta G, Greve T, Callesen H. 2000. Body dimensions, birth and organ weights of calves derived from in vitro produced embryos cultured with or without serum and oviduct epithelium cells. Theriogenology, 53:1761-1769.

Jakobsen, J, Østergaard T, Lund S, Brorsbøl M, Dagnæs-Hansen F, Liu Y, Li R, Schmidt M, Callesen H, Høyer S, Mapendano C, Orntoft T, Dyrskjøt L, Callesen M. 2014. Generating a porcine bladder cancer model. Transgenic Res, 23:889. (abstract)

Kragh PM, Vajta G, Corydon TJ, Purup S, Bolund L, Callesen H. 2004. Production of transgenic porcine blastocysts by hand-made cloning. Reprod Fertil Dev, 16:315-318.

Kuwayama M, Holm P, Jacobsen H, Greve T, Callesen H. 1997. Successful cryopreservation of porcine embryos by vitrification. Vet Rec, 141:365.

Liboriussen T, Makulska J, Callesen H. 1995. Genetic 
responsiveness of dairy cattle to superovulatory treatment. Acta Agric Scand, Sect A, Anim Sci, 45:99-105. Li J, Skovsgaard Pedersen H, Li R, Adamsen J, Liu Y, Schmidt M, Purup S, Callesen H. 2014. Developmental potential of pig embryos reconstructed by use of sow versus pre-pubertal gilt oocytes after somatic cell nuclear transfer. Zygote, 22:356-365.

Li J, Li R, Villemoes K, Liu Y, Purup S, Callesen H. 2015. Developmental potential and kinetics of pig embryos with different cytoplasmic volume. Zygote, 23:277-287.

Lin L, Luo Y, Sørensen P, Prætorius H, Vajta G, Callesen H, Pribenszky C, Bolund L, Kristensen TN. 2014. Effects of high hydrostatic pressure on genomic expression profiling of porcine parthenogenetic activated and cloned embryos. Reprod Fertil Dev, 26:469-484.

Liu Y, Østrup O, Li R, Li J, Vajta G, Kragh PM, Schmidt M, Purup S, Hyttel P, Klarke D, Callesen H. 2014. Long-term effect on in-vitro cloning efficiency after treatment of somatic cells with Xenopus egg extract in the pig. Reprod Fertil Dev, 26:1017-1031.

Liu Y, Li J, Lovendahl P, Schmidt M, Larsen K, Callesen H. 2015. In-vitro manipulation techniques of porcine embryos: a meta-analysis related to transfers, pregnancies and piglets. Reprod Fertil Dev, 27:429-439. Lopes AS, Larsen LH, Ramsing N, Løvendahl P, Räty M, Peippo J, Greve T, Callesen H. 2005. Respiration rates of individual bovine in vitro-produced embryos measured with a novel, non-invasive and highly sensitive microsensor system. Reproduction, 130:669-679.

Lopes AS, Greve T, Callesen H. 2007a. Quantification of embryo quality by respirometry. Theriogenology, 67:21-31.

Lopes AS, Madsen SE, Ramsing NB, Løvendahl P, Greve T, Callesen H. 2007b. Investigation of respiration of individual bovine embryos produced in vivo and in vitro and correlation with viability following transfer. Hum Reprod, 22:558-566.

Luo Y, Li J, Liu Y, Lin L, Du Y, Li S, Yang H, Vajta G, Callesen H, Bolund L, Sørensen CB. 2011. High efficiency of BRCA1 knockout using rAAV-mediated gene targeting: developing a pig model for breast cancer. Transgenic Res, 20:975-988.

Pedersen HS, Liu Y, Li R, Purup S, Løvendahl P, Holm P, Hyttel P, Callesen H. 2015. Selection of preversus postpubertal pig oocytes for parthenogenetic activation and somatic cell nuclear transfer. Reprod Fertil Dev, 27:544-550.

Purwantara B, Schmidt M, Greve T, Callesen $\mathbf{H}$. 1993. Follicular dynamics prior to and during superovulation in heifers. Theriogenology, 40:913-921.

Purwantara B, Callesen H, Greve T. 1994. Characterization of ovulation in superovulated cattle. Anim Reprod Sci, 37:1-5.

Schmidt M, Greve T, Callesen H. 1988. Superovulation of cattle using FSH containing standardized LH amounts. In: 11th International Congress on Animal Reproduction and AI, 1988, Dublin Ireland. Dublin, Ireland. pp. 191.

Schmidt M, Kragh PM, Li J, Du Y, Lin L, Liu Y, Vajta G, Callesen H. 2010. Pregnancies in and piglets from Large White sow recipients after two transfer methods of cloned embryos of different pig breeds. Theriogenology, 74:1233-1240.

Schmidt M, Winther KD, Dantzer V, Li J, Kragh PM, Du Y, Lin L, Liu Y, Vajta G, Sangild PT, Callesen H, Agerholm JS. 2011. Maternal endometrial oedema may increase perinatal mortality of cloned and transgenic piglets. Reprod Fertil Dev, 23:645-653.

Schmidt M, Winther KD, Secher JO, Callesen $\mathbf{H}$. 2015. Post-mortem findings in cloned and transgenic piglets dead before weaning. Theriogenology, 84:10141023.

Smith S, Holm P, Callesen H. 1994. Transfer of nuclei into activated cytoplasts. In: Proceedings. Association Européenne de Transfert Embryonnaire, 1994, Lyon, France: AETE. pp.248. (abstract).

Staunstrup NH, Madsen J, Primo MN, Li J, Liu Y, Kragh PM, Li R, Schmidt M, Purup S, DagnasHansen F, Svensson L, Petersen TK, Callesen H, Bolund L, Mikkelsen JG. 2012. Development of transgenic cloned pig models of skin inflammation by DNA transposon-directed ectopic expression of human $\beta 1$ and $\alpha 2$ integrin. PLoS One, 7:e36658.

Vajta G, Booth PJ, Holm P, Greve T, Callesen $\mathbf{H}$. 1997a. Successful vitrification of early stage bovine in vitro produced embryos with the Open Pulled Straw (OPS) method. Cryo Lett, 18:191-195.

Vajta G, Holm P, Greve T, Callesen H. 1997b. The submarine incubation system, a new tool for in vitro embryo culture. A technique report. Theriogenology, 48:1379-1385.

Vajta G, Holm P, Greve T, Callesen H. 1997c. Vitrification of porcine embryos using the Open Pulled Straw (OPS) method. Acta Vet Scand, 38:349-352.

Vajta G, Holm P, Kuwayama M, Booth PJ, Jacobsen H, Greve T, Callesen H. 1998. The Open Pulled Straw (OPS) vitrification: a new way to reduce cryoinjuries of bovine ova and embryos. Mol Reprod Dev, 51:53-58.

Vajta G, Peura TT, Holm P, Paldi A, Greve T, Trounson AO, Callesen H. 2000. New method for culture of zona-included or zona-free embryos: the Well of the Well (WOW) system. Mol Reprod Dev, 55:256264.

Vajta G, Lewis IM, Trounson AO, Purup S, Maddox-Hyttel P, Schmidt M, Pedersen HG, Greve T, Callesen H. 2003. Hand-made somatic cell cloning in cattle: analysis of factors contributing to the high efficiency in vitro. Biol Reprod, 68:571-578.

Vajta G, Alexopoulos NI, Callesen H. 2004. Rapid growth and elongation of bovine blastocysts in vitro in a three-dimensional gel system. Theriogenology, 62:12531263.

Vajta G, Callesen H. 2012. Establishment of an efficient somatic cell nuclear transfer system for production of transgenic pigs. Theriogenology, 77:1263-1274.

Viuff D, Richords L, Offenberg H, Hyttel P, Avery B, Greve T, Olsaker I, Williams J, Callesen H, Thomsen PD. 1999. A high proportion of bovine blastocysts produced in vitro are mixoploid. Biol Reprod, 60:1273-1278.

Xu KP, Greve T, Callesen H, Hyttel P. 1987. Pregnancy resulting from cattle oocytes matured and fertilized in-vitro. JReprod Fertil, 81:501-504. 